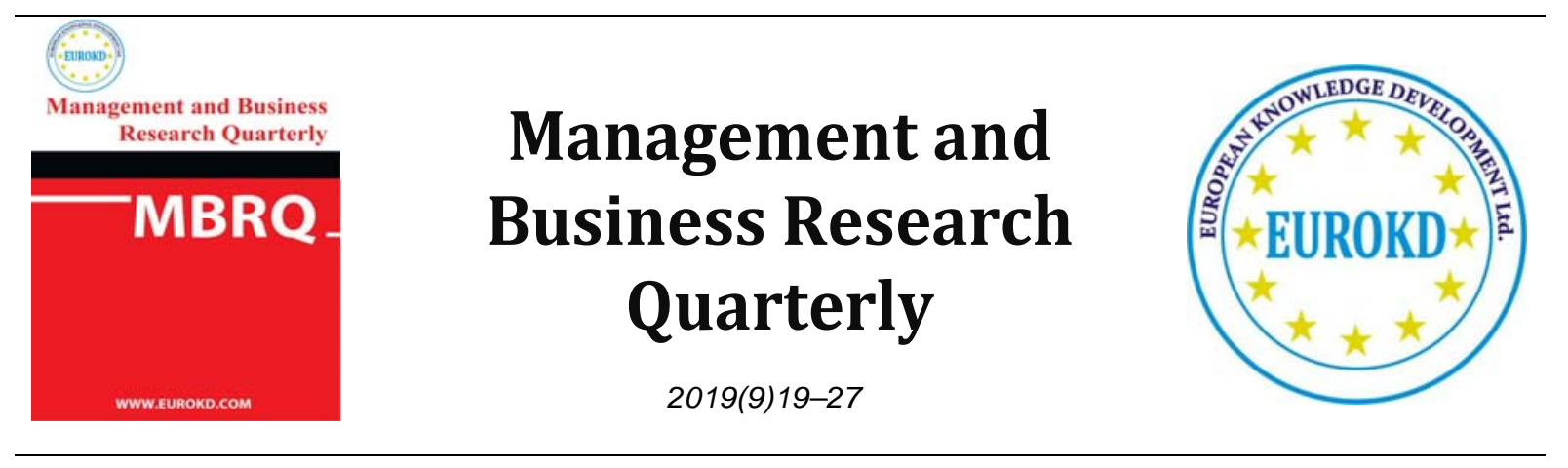

\title{
The Effect of Employee Work-Related Attitudes on Employee J ob Performance
}

\author{
Fidelis Ejeh Abba \\ Okan University, İstanbul, Turkey \\ Received 27 April 2019 Accepted 26 May 2019

\begin{abstract}
Since employee job performance is one of the essential factors for an organization to compete in this global market, the present study aims to explain the effect of work-related attitude on employee job performance in the Turkish aviation sector. The study used descriptive research design, and only secondary sources have been used to collect the date from the research articles, and a positive relationship attained. Attitudes are embedded in the minds of employees and then transpires from the employee's behavior.
\end{abstract}

Keywords: Digitalization, Top Management Teams, Public Listed Companies, Baltic States

\section{Introduction}

Work-related attitudes and the performance of organizations are the essential developmental study in various service industries.

The connections between these factors are integral in every organization for affirming the efficiency of a business enterprise. Various studies that checked the level of the fecundity of the same industries and establishments discovered that some enterprises relentlessly operate much more efficiently than others. (Gibbons, R., \& Henderson, R. 2012).

To accomplish employee and organizational objectives through their performance are most valuable for work-related attitude in service industries. Therefore, the study at this time for work- 
related attitudes are designed to focus on variables that are considered to affect workplace behavior of employee, leadership, job satisfaction, job involvement, organizational commitment, job performance.

According to Amos \& Ristow (2004), to accomplish organizational goals and objectives, the study of effective management of job performance are crucial. The responsibility of human resource management practices in similar enterprises that explained the persistent productivity differences are now receiving considerable weight in both intra-industrial and cross-industrial studies (Bandiera et al. 2007).

An important parameter to consider in every profession is job performance. In every service, industries, and professional practices, job performance is thought-out as one of the critical factors building the growth of the system (C Platis 2015).Generally, the work of the Manager is to assign responsibilities and give instructions to coworkers. The inside information regarding the available link between manager-worker relation and job performance would allow the application of appropriate structures for the organization and consequently lead to better output for the business. Committed and satisfied jobholders are unlikely to indicate low performance and are regularly highly productive jobholders who identify with organizational values and goals. The popularity of work attitudes concepts originated from its linkage with several employees' work behaviors (Samad, 2011).

(Fritzsche and Parrish 2005) states that "A happy worker is a productive worker." This anticipation sets a significant role in deciding employee attitude and employee work performance. The attitude of jobholder has a direct impact on job performance. Other various variables impact jobholder job-related attitude on jobholder job performance. The study focuses on variables that are considered to affect related mood and behavior of jobholders such as Job Satisfaction, Organization Commitment, Job Involvement, and Job Performance.

Though previous research prominence has been in line with Newstorm and Davis (1993), attitudes are reasonably good predictors of behaviors. They provide hints to an employee's behavioral intendments or tendency to act in a specific manner. Positive job attitudes help to anticipate constructive action while a negative attitude towards job help to anticipate undesirable behavior.

Work-related attitude and jobholder performance studies had already been carried out by a lot of Developing and developed nations, but there are no studies in the Turkish Aviation sector, most notably in the airline companies in Istanbul. Hence this study aims to inquire about the effect of work-related attitudes on jobholder's performance. To contribute the other reviews, the researcher has undertaken this study.

\section{Research Problem}

The behavior of jobholders at work affects their job performance. Job performance of a jobholder is concerned with two aspects. Firstly, jobholders should execute their job in a way that will lead to the accomplishment of a desirable result. Secondly, jobholder needs to use organizational resources efficiently by preventing or underrating waste in performing job activities. Attitudes have significant effects on the behavior of the person at work. Some areas of views that a person working concerns himself or herself with are in the field of superiors, subordinates, peers, supervision, pay, 
benefits, promotions or anything that prompt positive or adverse reactions. These attitudes demonstrate a particular person's dislikes and like towards other persons, objects, events, and activities in that persons' encircling environment. Some of the extreme attitudes are likely to affect persons' behavior, and this makes the eagerness to study and know about approaches.

Empirical studies found out the connection between employee job attitudes and employee job performance. A remarkably high number of these studies in the western framework was done. In other to fill this research gap that requires the attention of researchers to help build further theories and literature of the jobholder work-related attitudes and job performance. However, just a few nominal experimental types of research have been conducted to investigate the effect of workrelated attitudes on employee job performance in Aviation service industry, especially airline jobholders in Istanbul.

Although there are quite many related researches in this area in Turkey, a few have been conducted in Istanbul context. After surveying different articles about job attitudes and job performance, the researcher found that there are a lot of articles discussing the relationship between job attitudes and job performance. But a limited amount of articles talked about the mechanism of how job attitudes affect job performance. For example, when flight attendant had different job attitude, is the performance of the jobholder affected? Another instance if airline counter operator for checking in passenger had different job attitude, is the performance of the jobholder affected? To fill this gap up, the researcher has undertaken this study.

\section{Objective of the Study}

The general reviews purpose is to identify the effect of the work-related attitudes on the job performance of the jobholders of Airline companies in Istanbul, Turkey. The study strived to accomplish the following clear-cut objectives.

1) Identifying the relationship between job satisfaction and job performance of the jobholders of Airline companies in Istanbul, Turkey.

2) Determining the relationship between organizational commitment and job performance of the jobholders of Airline companies in Istanbul, Turkey.

3) Identify the accord between job involvement and job performance of the jobholders of Airline companies in Istanbul, Turkey.

4) To find the impact of work-related attitudes on job performance of the jobholders of Airline companies in Istanbul, Turkey.

\section{Research Question}

The following questions navigated the research.

1) Is there any accord between job satisfaction and job performance of the jobholders of Airline companies in Istanbul, Turkey?

2) Is there any relationship between job involvement and job performance of the jobholders of Airline companies in Istanbul, Turkey? 
3) Is there any accord between organizational commitment and job performance of the jobholders of Airline companies in Istanbul, Turkey?

4) Do employee work-related attitudes effect on employee job performance?

\section{Literature Review}

\section{Work Related Attitudes}

The most widely accepted definition of an attitude, however, was provided by Eagly \& Chaiken (1993, p. 1) and cited by (Timothy A. J and John D 2012). Attitude is a psychological bias that is expressed by evaluating a particular entity with some degree of favor or disfavor." Therefore, the perception of evaluation is a unifying theme in attitudes research.

Robbins (2003) explained attitudes as evaluative statements that can either be favorable or unfavorable-concerning objects, people, or events. Therefore, they reflect on how one feels about something. Encouraging reports may contribute positive effects in respect to the object, person, or event involved with, whereas adverse statement may help negative effects. An attitude is either feeling a negative or positive or mental state of preparedness, acquired and organized via knowledge that made use of exact influence on a person's response to situations, individuals, and objects. This definition of attitude has positive implications for managers. First, people learn attitudes. Secondly, attitudes define one's willingness concerning given aspects of the world. Thirdly, attitudes add emotional basis of one's social relationship and identification with others. And fourthly, attitudes are coordinated and are closed to the core of a person's character. Some attitudes are constant and enduring; yet, like each of the psychological variables, attitudes are subject to change (Fishbein and Ajzen, 1974)

Discussing further attitudes, these are the feelings jobholders have concerning various conditions of the work environment. There are three deceive attitudes, and they are Job involvement, job satisfaction, and organizational commitment. These three decisive attitudes are the most appropriate to essential outcomes. Therefore, the study at this time is used to measure the job attitude of the jobholders with the help of following variables such as job satisfaction, job involvement, and organizational commitment.

\section{Job Satisfaction}

Job Satisfaction is a positive feeling about an individual's job as a result of an evaluation of its characteristics or a person's emotional response at work or to work. Job satisfaction portrays how happy people are with their job. Job satisfaction is also a substantial attitude that influences jobholders' behaviors in the workplace.

According to Locke (1976), job satisfaction simply means positive or satisfying emotional state that is resulting from the appraisal of employee's job and job experiences. The elated a person is with his job or her job, the higher the level of his work satisfaction or her work satisfaction. Job satisfaction is an array of favorable or unfavorable feelings and emotions with which jobholders view their job. Contained in Locke's definition is the importance of both effect, or feeling, and cognition or thinking. When we are thinking of the feelings about what we believe. Contrarily, when we have feelings, we think about what we feel. Perception and effect are thus inextricably 
linked, in our psychology and even in our biology (Saari and Judge, 2004). Robbins (2003) sees job satisfaction as the general attitude of an individual toward his/her job. Smith, Kendall, and Hulin (1969), described job satisfaction is the degree to which employee's are gratified or fulfilled by their work. Comprehensive studies on job satisfaction show that individual factors such as a person's needs and ambitions determine this attitude, along with the group and organizational factors such as relationships with coworkers, supervisors, working conditions, work policies, and compensation. Therefore, organizational behavior researchers are interested in accurately measuring job satisfaction and understanding its consequences for individuals at work (Wood et al., 1976).

\section{Organizational Commitment}

According to Wood (1996), organizational commitment is the degree to which a people strongly identifies with and feels like a part of the organization. Allen and Meyer (1990) have recognized commitment in three forms. They are an effective commitment, continuance commitment, and normative commitment. Affective commitment is related to the person "s emotional affinity to their organization. Continuance commitment is an individual's understanding of the risk and costs correlated with leaving their current organization. Normative commitment is a moral dimension based on an individual's sense of obligation and responsibility to their employing organization.

Greenberg and Baron (2003) described organizational commitment as the degree to which an individual distingushes and is participating with his or her organization and is unwilling to leave it. Jobholders willingness to engage in organizational affairs and interest to remain in the organization as the organizational commitment was highlighted in this definition.

\section{Job Involvement}

Job involvement relates to the technique of engaging workers in their job and developing their participation in decision- making. Li and Long (1999) define job involvement as the degree to which one show emotional or mental identification with his job. Management needs to understand the importance of job involvement as it is one of the most important and essential elements of job behavior by the whole of the workforce as previous research had proven this phenomenon (Manojlovich, Laschinger, \& Heather, 2002). It was emphasized that by giving workers power over their work content, that is a decision regarding rapidity of job, quality of the product, job-related abilities and the resources can motivate the employees to enhance their job involvement. Generally, a workplace appraised as consisting of motivated employees, willing to do more than just put in their time, 'is apt to be interpreted as beneficial (James, James, and Ashe, 1990). Workers with a high level of job involvement are strongly identified with, and they care about the kind of work they do. Job involvement is the magnitude to which employees deeply involve themselves in their jobs, invest their energy and time in them, and view work as a principal part of their general lives (Newstrom and Devis, 1993). Job involvement is the eagerness of a person to work hard and apply effort beyond normal job expectations (Wood, 1996)).

\section{Job Performance}


Job performance is among the most important dependent variables. All the employees working within the organization are expected to perform their job dependably. They are responsible for the successful performance of duties and tasks assigned to them at the workplace according to their employment contract. Jobholders accept specific job assignments and agree to do them dependably. Job performance is the achiement of those tasks that comprise a person's job (Porter and Lawler, 1968,). The duties that should be carried out are different from one work to another. According to Moorhead and Griffin (1999), job performance is made up of all work-related behavior. Employee's job performance has been described as work performance in terms of quantity and quality expected from each employee (Khan et al., 2010).

\section{Reviews of Empirical Evidence}

Wei and Chu (2008) performed a survey about the relationship between attitude toward work, and job performance in the financial service industry and they found that work attitude has a positive effect on job performance. Excellent job performance is as a result of an improved work attitude. Based on the above, this study predicts that employee's attitude towards work has a significant positive effect on employee's job performance. Rahman and Kodikal (2017) carried out research which indicated that there is substantial and positive relationship between work-related attitude and job performance.

Vroom (1964) stated that it was commonly assumed by a lot of people associated with the human relations act that job satisfaction was positively associated with job performance. Human relations could be described as an endeavor to increase productivity by satisfying the needs of employees and subsequently increase job performance. Hettiarachchi and Jayarathna (2014) found that there was a positive relationship between job satisfaction and job performance.

Suliman and Lles (2000) carried out research on full-time employees working with three companies of the industrial sector in Jordan and explored that continuance organizational commitment has a positive association with employee job performance. Also, Khan et al. (2010) between these two variables. Leong et al. (1994) and Wright (1997) performed a study about organizational commitment and employee's job performance and found a very weak, or negative or insignificant relationship between the two. According to Benkhoff (1997) and cited by Qaisar et al. (2011), believes that deviation arises due to the way commitment has been gestated. Based on the above, this study predicts that organizational commitment has a significant positive effect on an employee's job performance.

Malini. G and Atchyuthan. N (2016) also found that there was a positive relationship between job involvement and job performance. The perceived relationship was positive and moderately strong. Therefore, there was statistical evidence to claim that job involvement and job performance were positively related. Rahman and Kodikal (2017) performed a surfer which shows that job involvement and productivity of the employees have a significant relationship.

\section{Model}


Independent Variables Dependent Variables

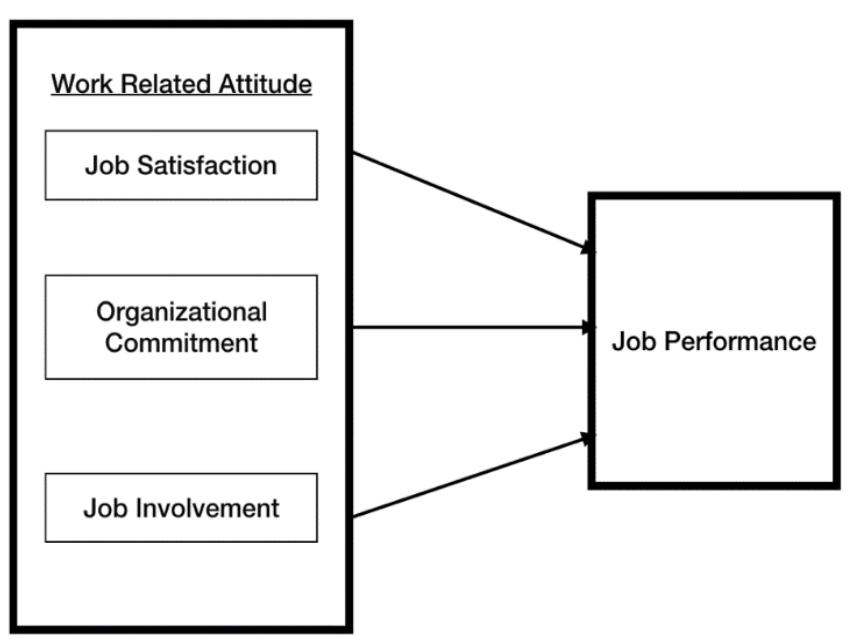

Fig 1: Conceptual Framework of the Model of the Study

\section{Hypotheses}

In this research, the following hypotheses were formulated.

1. H1: A positive relationship exist between job satisfaction and job performance of jobholders of Airline companies in Istanbul, Turkey.

H0: (otherwise)

2. H1: A positive relationship exist between job involvement and job performance of jobholders of Airline companies in Istanbul, Turkey.

H0: (Otherwise)

3. H1: A positive relationship exist between organizational commitment and job performance of jobholders of Airline companies in Istanbul, Turkey.

H0: (Otherwise)

4. H1: There is a significant impact of work-related attitudes on job performance of jobholders of Airline companies in Istanbul, Turkey.

H0: (Otherwise)

\section{Discussion and Conclusion}

Based on previous empirical studies and findings it can be concluded that there is a relationship between work-related attitude and job performance. In this competing period of time, the sustainability of an organization is important therefore, employees being the core competencies of any organization need to be forecasted to meet the organizational objectives and be more productive. The studies have shown that the job performance of employees and their work-related attitudes (Job Satisfaction, Organizational Commitment, and job involvement) are significantly and positively related. 
Studies also showed that job satisfaction is a good predictor for job performance of jobholders. Job Satisfaction is the most important factor that improves employee job performance in various organizational sectors, followed by job involvement and organizational commitment.

Finally, findings of previous researches lead us to the conclusions that there is a significant positive relationship between job satisfaction and employee performance, likewise for organizational commitment and job performance, there is a significant positive relationship between them.

Employees performance depends on their attitude towards their jobs and organizations. If workers have a positive attitude to their work, e.g. If an employee if very satisfied at work, given a chance to be very much involved in his/her job, it will result in a high work efficiency and thus leads to the employee to be more committed to the organization and then result in a higher job performance by the employee. The previous researches show that such an employee will have a positive work-related attitude towards his/her job. Thus, it leads to the conclusion that to keep and increase organizational profitability, Values or meet their set goals and values, the organizations need to take more initiatives to create a workforce dynamics with positive related attitude to boost up the organizational productivity.

\section{References}

Gibbons, R., \& Henderson, R. (2012). What do managers do? : Exploring persistent

Amos, T.L., Ristow, A., and Ristow, L. 2004. Human Resource Management (2nd Edition). Lansdowne: Juta and Co Ltd.

Bandiera, O., Barankay, I., \&Rasul, I. (2007). Incentives for managers and inequality among workers: evidence from a firm-level experiment. The Quarterly Journal of Economics, 122(2), 729-773.

Platis, C., Reklitis, P., \&Zimeras, S. (2015). The relation between job satisfaction and job performance in healthcare services. Procedia-Social and Behavioral Sciences, 175, 480-487.

Samad, S. (2011). The effects of job satisfaction on organizational commitment and job performance relationship: A case of managers in Malaysia's manufacturing companies. European Journal of Social Sciences, 18(4), 602-611.

Fritzsche, B. A., \& Parrish, T. J. (2005). Theories and research on job satisfaction. Career development and counseling: Putting theory and research to work, 180-202.

Newstorm, J. W., \& Davis, K. (1993). Organizational Behaviour: Human Behaviour at Work. (9. Bs.).

Timothy A. Judge and John D. Kammeyer-Mueller (2012) Job Attitudes Annual Review of Psychology 63:1, 341-367

Robbins, S. P., \& Judge, T. (2003). Essentials of organizational behavior (Vol. 200, No. 1). Upper Saddle River: Prentice Hall.

Fishbein, M., \& Ajzen, I. (1974). Attitudes towards objects as predictors of single and multiple behavioral criteria. Psychological Review, 81(1), 59 .

Locke, E. A. (1976). The nature and causes of job satisfaction. Handbook of industrial and organizational psychology, 1, $1297-1343$.

Saari, L. M., \& Judge, T. A. (2004). Employee attitudes and job satisfaction. Human Resource Management: Published in Cooperation with the School of Business Administration, The University of Michigan and in alliance with the Society of Human Resources Management, 43(4), 395-407.

Smith, P.C., L.M. Kendall, and C.L. Hulin (1969). The Measurement of Satisfaction in Work and Retirement. Chicago: Rand McNally.

Wood, Olin R. (1976). Measuring Job Satisfaction of the Community College Staff

Wood, S. (1996). High commitment management and payment systems. Journal of Management Studies, 33: 53-57.

Allen, N. J., \& Meyer, J. P. (1990). The measurement and antecedents of affective, continuance, and normative commitment to the organization. Journal of Occupational Psychology, 63, 1-18 
Greenberg, J., \& Baron, A. B. (2003). Behavior in organizations (8 ed.). Upper Saddle River, NJ: Prentice Hall

Li Ye, \& Long Lirong. (1999). A literature review on job involvement. Social Psychological Research, (4): 57-63 (in Chinese).

Manojlovich, M., and H.K.S. Laschinger. 2002. "The Relationship of Empowerment and Selected Personality Characteristics to Nursing Job Satisfaction." Journal of Nursing Administration 32(11): 586-95.

James, Lawrence R., Lois A. James, and Donna K. Ashe. (1990). —The Meaning of Organizations: The Role of Culture and Values.॥ Pp. 282-313 in Organizational Climate and Culture, edited by B. Schneider. San Francisco: Jossey Bass.

Newstrom, J.W. \& Davis, K. (1993). Organizational behavior: Human behavior at work. New York: McGraw Hill.

Wood, S. (1996). High commitment management and payment systems. Journal of Management Studies, 33: 53-57.

Porter, L.W. and Lawler, E.E. (1968), Managerial Attitudes and Performance, Irwin- Dorsey, Homewood, IL

Moorhead, G., and Griffin, R.W. (1999), Organizational Behaviour: Managing People and Organization, 3rd Ed, Mumbai: Jaico Publishing House.

Khan, H. Razi, A., Ali, S.A, and Asghar A. (2010) A study on the relationship between organizational job commitment, and its determinants among C.S.R.s and managerial level employees of Pakistan (Telecommunication sector), Interdisciplinary Journal of Contemporary Research in Business, 3, 11, 269-284.

Wei, W. C., and the Chu, S. H., Empirical Study on the Correlation among Personality Traits, Job Attitudes, Quality Service, Job Performances and Customers' Satisfaction - A Financial Holding Company in Taiwan, International Journal Lisrel, 1(2), 2008, pp. 1-24.

Rahman, Habeeb \& Kodikal, Rashmi. (2017). Impact of Employee Work-Related Attitudes on Job Performance. British Journals ISSN 2048-125X. 13. 93-105.

Vroom, V. H. (1964). Work and Motivation, New York: Wiley.

H.A.H., Hettiarachchi \& Jayarathna, Dinethi Yasodara. (2014). The effect of Employee Work-Related Attitudes on Employee Job Performance: A Study of Tertiary and Vocational Education Sector in Sri Lanka. IOSR Journal of Business and Management. 16. 74-83. 10.9790/487X-16447483.

Surinam, A., and LIes, P., Is Continuance Commitment Beneficial to Organizations? Commitment-performance Relationship: New Look, Journal of Managerial Psychology, 15 (5), 2000, pp. 407-422.

Leong, S. M, Randoll, D. N., and Cote, J. A., Exploring the Organizational Commitment- Performance, Journal of Business Research, 29 (1), 1994, pp.57-63.

Wright, T. A., Job Performance and Organizational Commitment, Perceptual and Motor Skills, 85(2), 1997, pp.447-50.

Qaisar, M. U., Rehman, M. S., and Suffyan M., Exploring Effects of Organizational Commitment on Employee Performance: Implications for Human Resource Strategy, Interdisciplinary Journal of Contemporary Research in Business, 3(11), 2011, pp. 248-255.

Malini. G and Atchyuthan. N (2016) The effect of Employee Work-Related Attitudes on Employee Job Performance: A Study of Non-Academic Staffs (Skilled Labors) of the University of Jaffna. Proceeding of International Conference on Contemporary Management (ICCM 2016), pp 773788

Rahman, Habeeb \& Kodikal, Rashmi. (2017). Impact of Employee Work-Related Attitudes on Job Performance. British Journals ISSN 2048-125X. 13. 93-105. 